\section{Health and work in Brazil: physical and psychosocial demands}

\author{
Saúde e trabalho no Brasil: demandas físicas e \\ psicossociais
}

\section{Salud y trabajo en Brasil: exigencias físicas y psicosociales}

Patrícia Pinheiro de Freitas 1

Mariana Souza Lopes 1

Ada Ávila Assunção 1

Aline Cristine Souza Lopes 1

\begin{abstract}
This study aims to describe the prevalence and factors associated of physical and psychosocial demands among Brazilian workers. Data were obtained from the 2013 Brazilian National Health Survey. Physical demand was defined as jobs that require intense physical effort or excessive walking, whereas psychosocial demand was defined as involvement in stressful activities. Multivariate logistic regression was used to estimate the association between demands and health conditions, occupational characteristics, and work conditions. Out of 39,590 participants, 54.4\% reported physical demands and 35.5\% psychosocial demands at work. After adjustment for sociodemographic characteristics, health conditions, occupational characteristics, and work conditions remained significantly associated with physical or psychosocial workload. The results suggest that in Brazil the work has a high level of physical and psychosocial demands, which are associated with occupational features and health conditions. It is necessary to incorporate work activities as significant factors to investigate the causes of diseases. And the interventions and policies aimed at preventing the negative occupational exposures are urgent, and can contribute to improve physical and psychosocial health at the workplace.
\end{abstract}

Occupational Health; Working Conditions; Workplace, Work Stress

\section{Correspondence}

Escola de Enfermagem, Universidade Federal de Minas Gerais.

Av. Alfredo Balena 190, sala 316, Belo Horizonte, MG 30130-100, Brasil.

alinelopesenf@gmail.com

1 Universidade Federal de Minas Gerais, Belo Horizonte, Brasil. 


\section{Introduction}

Work-related diseases are common 1. Working conditions and the nature of employment can affect health and well-being, work productivity, and workplace safety 2,3. Adverse psychosocial factors in terms of high job demands or low job control have been associated with sickness and absence at work ${ }^{4}$. Also, the physically hard work has been associated with musculoskeletal pain 5 .

Occupational stressors can trigger illnesses and cause significant dysfunctions 6 . There are associations between physical and psychosocial workload of oil industry workers and sleep disorders, high blood pressure and musculoskeletal disorders 7; public service or freight handlers and musculoskeletal pain 8,9,10; depression disorder and the teacher category 11; noise and shift work has been associated with hypertension 12 . However, this association has not yet been investigated in a national sample of workers, especially when it comes to the context of developing countries and with constant changes in the workforce.

In recent decades, studies on workers' health have identified the association between exposure to occupational risks and a greater chance of becoming ill 13. When sick, if protected, the workers will have the right to leave for treatment. However, many workers attend the work, even when they are weakened by the symptoms and sequels resulting from clinical conditions. In the informal labor market, this may be even more frequent. The manifestations of physical and psychological incapacity reveal the degree of effort required to respond to the physical and psychosocial demands of work ${ }^{14}$. In this sense, when the demands are high, workers who are sick or have few resources are likely to feel embarrassed or pressured by the difficulties they face. Thus, the effort to perform the tasks, in a situation of decreased physical, cognitive, and emotional capacities, can lead to exhaustion 15,16 . If exhausted, they will be less empowered to carry out their work activities, constituting a loss spiral 17 .

In this sense, the diagnosis of work and health characteristics in Brazil, and their association with physical and psychosocial demands may help elaborate measures to protect workers' health. Moreover, such study may raise awareness among policy makers, especially those involved in the revision of labor laws in Brazil, to review what may be contrary to the improvement of working conditions. Thus, this study used data from a large population-based survey to investigate the prevalence and factors associated with physical and psychosocial demands among Brazilian workers.

\section{Methods}

\section{Data source and study population}

This cross-sectional study used data from the 2013 Brazilian National Health Survey (PNS, in Portuguese) in Brazil, a population-based survey conducted by the Brazilian Institute for Geography and Statistics (IBGE, in Portuguese), in partnership with the Brazilian Ministry of Health. This survey aims to assess the health, lifestyle, and the use of health services.

A three-stage cluster sampling was performed: (1) census tracts form the primary sampling units, selected by random sampling; (2) households compose the secondary sampling units; and (3) adults aged $>18$ years form the tertiary sampling units. Adults were selected from a list of eligible residents at the time of interview. Details about the sampling process were published elsewhere 18 .

Data were collected face-to-face from August 2013 to February 2014, in 62,986 households among the 81,767 randomly individuals sampled ${ }^{19}$. A total of 60,202 people participated in the individual interviews 18. The data collection instrument is available at the PNS website (https://www. ibge.gov.br/estatisticas/sociais/saude/9160-pesquisa-nacional-de-saude.html).

This study included selected adults who reported a job or internship paid in money or products, informal paid work, or unpaid work. 


\section{Physical and psychosocial demands}

Physical demand at work was defined by a positive response in at least one of the questions: "In your job, do you walk a lot?" and "In your job, do you do heavy cleaning, heavy lifting, or any other activity that requires intense physical effort?". The first question is original of the PNS, and the second is widely used in others occupational surveys 20,21,22,23.

Despite the possibility of measurement bias when non-validated questions are used, the answer to the first question was included in the elaboration of the variable physical demand for work. Two reasons justify this procedure, firstly, because of the characteristics of work in Brazil. In 2012 and $2013,45.1 \%$ and $45.3 \%$, respectively, of the employed persons worked in the services activity group 24 . In this contingent, standing work for long periods is a frequent condition, as seen in the groups of commercial workers, teachers, health personnel, among others 24 . Furthermore, the proportion of musculoskeletal diseases attributable to the demands of physical work is greatly significant in this population making this condition relevant to the study, although with limitations in the investigation. Thus, the joint use of the variables could possibly result in losses in the identification of this important contingent of workers in Brazil. The second reason is related to the data collected, the national surveys cited incorporate more than one question to assess physical demand at work, but none of the complementary questions used are included in the PNS.

Psychosocial demand at work was assessed by the following question: "Thinking about all of your work, are you exposed to any of these factors that may affect your health?". A positive response to the sub-item referring to "involvement in activities that lead to nervousness" was defined as psychosocial demand. The nervousness is a possible manifestation in the causal chain of occupational stress, besides reproducing the manifestation of anxiety in common sense. Generally, nervousness is a manifestation of the nervous system, represented by a shaken behavior 25 .

\section{Explanatory variables}

Factors associated with the presence of physical and psychosocial demands were analyzed in two blocks of variables: (1) health conditions and (2) occupational features.

Health conditions evaluated were: self-reported conditions (diabetes, hypertension, work-related musculoskeletal disorder - WMSD, depression, and chronic back pain), smoking (yes, no), self-rated health (very good/good, regular/poor/very poor), and nutritional status (underweight, adequate preobesity, and obesity).

Occupational features evaluated were: number of current jobs (one, two or more), working night shifts (yes, no), open or closed work environment (closed, open, both), time at the current job (up to 2 years, 2 to 10 years, more than 10 years), working 24 hour shifts (yes, no), weekly workload (up to 20 hours, 20 to 40 hours, more than 40 hours).

Weight and height were measured at the time of the individual's interview. Nutritional status was verified according to the recommendations of the World Health Organization (WHO) 26.

\section{Covariates}

Individual sociodemographic characteristics included sex (female, male), age (18-24 years, 25-34 years, 35-44 years, 45-54 years, and $\geq 55$ years old), educational level (illiterate/no formal education, elementary school, high school, higher education), marital status (married/have a partner, separated/ divorced/widowed or widower, never married) that could have confounded the association of health and work conditions with physical and psychosocial demands.

\section{$\underline{\text { Statistical analysis }}$}

Analyses were performed in the Stata software, version 14 (https://www.stata.com), and accounted for the sampling complex design and unequal selection probabilities. Variables were described by frequencies and $95 \%$ confidence intervals $(95 \% \mathrm{CI})$. 
Demographics, occupational features and health conditions were described according to the presence of physical and psychosocial demands.

Factors associated with physical and psychosocial demands were investigated with univariate and multivariate logistic regression models. Models were constructed for each block of variables (health conditions, occupational features) and adjusted for socio-demographics characteristics. For all models, the possibility of multicollinearity for explanatory variables was tested. Only variables with no multicollinearity relationship were maintained in the models. A 5\% significance level was adopted.

\section{Results}

Out of 39,590 Brazilian workers, 57.1\% (95\%CI: 56.2-58.1) were male, 26.8\% (95\%CI: 26.0-27.6) had 25-34 years old, and 37.5\% (95\%CI: 36.6-38.4) had complete high school (Table 1). The main self-reported health conditions were hypertension (15.7\%; 95\%CI: 15.0-16.4) and chronic back pain (16.3\%; 95\%CI: 15.6-17.1). The prevalence of smoking was 15.2\% (95\%CI: 14.6-15.9). Most workers self-rated their health as "very good" or "good" (73.4\%; 95\%CI: 72.6-74.2), and 19.5\% (95\% CI: $18.7-$ 20.3) were classified as obese (Table 2).

The prevalence of physical demand in Brazilians was 53.9\% (95\%CI: 52.9-54.9) and of psychosocial demand was 35.2\% (95\%CI: 34.2-36.3). After adjustment for sociodemographic characteristics, different health conditions were associated with occurrence of physical and psychosocial demand (Table 2).

\section{Table 1}

Characteristics of Brazilian workers by presence of physical and psychosocial demands. 2013 Brazilian National Health Survey.

\begin{tabular}{|c|c|c|c|}
\hline Characteristics & $\begin{array}{l}\text { Brazilian } \\
\text { workers } \\
\%(95 \% \mathrm{Cl})\end{array}$ & $\begin{array}{l}\text { Physical } \\
\text { demand } \\
\%(95 \% \mathrm{Cl})\end{array}$ & $\begin{array}{c}\text { Psychosocial } \\
\text { demand } \\
\%(95 \% \mathrm{Cl})\end{array}$ \\
\hline \multicolumn{4}{|l|}{ Age (years) } \\
\hline $18-24$ & $15.7(14.9-16.3)$ & $15.8(15.6-17.4)$ & $16.3(15.4-17.2)$ \\
\hline $25-34$ & $26.8(26.0-27.6)$ & $25.2(24.0-26.0)$ & $25.0(23.6-25.9)$ \\
\hline $35-44$ & $23.9(23.1-24.7)$ & $24.3(23.2-25.3)$ & $22.8(21.8-23.8)$ \\
\hline $45-54$ & $19.9(19.0-60.6)$ & $20.8(19.9-21.8)$ & $20.5(19.6-21.4)$ \\
\hline 55 or older & $13.7(13.1-14.4)$ & $13.9(13.0-14.8)$ & $15.4(14.6-16.3)$ \\
\hline \multicolumn{4}{|l|}{ Sex } \\
\hline Male & $57.1(56.2-58.1)$ & $62.3(61.0-63.6)$ & $58.6(57.2-60.1)$ \\
\hline Female & $42.9(41.9-43.8)$ & 37.7 (36.4-39.0) & $41.4(39.9-42.8)$ \\
\hline \multicolumn{4}{|l|}{ Education level } \\
\hline Illiterate/No formal education & $30.2(29.2-31.1)$ & $37.5(36.2-38.8)$ & $34.5(33.9-36.0)$ \\
\hline Elementary school & $16.0(15.3-16.7)$ & $17.6(11.8-13.7)$ & $16.9(16.1-17.8)$ \\
\hline High school & $37.5(36.6-38.4)$ & $34.4(33.1-35.6)$ & $34.9(33.8-36.0)$ \\
\hline Higher education & $16.3(15.4-17.3)$ & $10.5(9.7-11.3)$ & $13.2(12.4-14.2)$ \\
\hline \multicolumn{4}{|l|}{ Marital status } \\
\hline Have a partner & $44.7(43.7-45.6)$ & $42.8(41.6-44.1)$ & $43.4(42.2-44.6)$ \\
\hline Separated/Divorced/Widowed or widower & $9.5(9.0-10.1)$ & $9.2(8.4-10.0)$ & $9.7(9.0-10.3)$ \\
\hline Never married & $45.8(44.9-46.8)$ & $48.0(46.7-49.2)$ & $46.9(45.7-48.1)$ \\
\hline
\end{tabular}

95\%Cl: 95\% confidence interval. 
Table 2

Health conditions of Brazilian workers according to the presence of physical and psychosocial demands. 2013 Brazilian National Health Survey.

\begin{tabular}{|c|c|c|c|c|c|c|c|}
\hline \multirow[t]{2}{*}{ Characteristics } & \multirow{2}{*}{$\begin{array}{c}\text { Brazilian } \\
\text { workers } \\
\%(95 \% \mathrm{Cl})\end{array}$} & \multicolumn{3}{|c|}{ Physical demand } & \multicolumn{3}{|c|}{ Psychosocial demand } \\
\hline & & $\%(95 \% \mathrm{Cl})$ & $\begin{array}{l}\text { Unadjusted OR } \\
\qquad(95 \% \mathrm{Cl})\end{array}$ & $\begin{array}{l}\text { Adjusted * OR } \\
(95 \% \mathrm{Cl})\end{array}$ & $\%(95 \% \mathrm{Cl})$ & $\begin{array}{l}\text { Unadjusted OR } \\
\qquad(95 \% \mathrm{Cl})\end{array}$ & $\begin{array}{c}\text { Ajusted * OR } \\
(95 \% \mathrm{Cl})\end{array}$ \\
\hline \multicolumn{8}{|l|}{ Hypertension } \\
\hline No & $84.3(83.6-85.0)$ & $84.4(83.5-85.4)$ & Reference & Reference & $83.9(82.6-85.2)$ & Reference & Reference \\
\hline Yes & $15.7(15.0-16.4)$ & $15.6(14.6-16.5)$ & $0.97(0.88-1.07)$ & $0.91(0.82-1.02)$ & $16.1(14.8-17.4)$ & $1.04(0.93-1.17)$ & $1.23(1.09-1.39)$ \\
\hline \multicolumn{8}{|l|}{ Diabetes mellitus } \\
\hline No & $96.2(95.8-96.6)$ & 96.4 (95.9-96.9) & Reference & Reference & $96.2(95.6-96.9)$ & Reference & Reference \\
\hline Yes & $3.8(3.4-4.2)$ & $3.6(3.1-4.1)$ & $0.88(0.73-1.07)$ & $0.82(0.67-1.02)$ & $3.8(3.1-4.4)$ & $0.98(0.79-1.23)$ & $1.17(0.93-1.47)$ \\
\hline \multicolumn{8}{|l|}{ WMSD } \\
\hline No & $97.2(96.9-97.5)$ & $97.2(96.8-97.6)$ & Reference & Reference & $95.8(95.2-96.4)$ & Reference & Reference \\
\hline Yes & $2.8(2.5-3.1)$ & $2.8(2.4-3.2)$ & $0.99(0.79-1.25)$ & $1.19(0.94-1.50)$ & $4.2(3.6-4.8)$ & $2.10(1.68-2.62)$ & $2.10(1.68-2.63)$ \\
\hline \multicolumn{8}{|l|}{ Depression } \\
\hline No & $93.8(93.3-94.3)$ & $93.8(93.2-94.4)$ & Reference & Reference & $91.6(90.8-92.5)$ & Reference & Reference \\
\hline Yes & $6.2(5.7-6.7)$ & $6.2(5.6-6.8)$ & $1.01(0.86-1.17)$ & $1.16(0.99-1.37)$ & $8.4(7.5-9.2)$ & $1.73(1.49-2.01)$ & $1.98(1.68-2.32)$ \\
\hline \multicolumn{8}{|l|}{ Chronic back pain } \\
\hline No & $83.7(82.9-84.4)$ & $81.8(80.8-82.8)$ & Reference & Reference & $81.4(80.2-82.7)$ & Reference & Reference \\
\hline Yes & $16.3(15.6-17.1)$ & $18.2(17.2-19.2)$ & $1.36(1.24-1.50)$ & $1.32(1.20-1.47)$ & $18.6(17.3-19.8)$ & $1.28(1.16-1.42)$ & $1.51(1.35-1.68)$ \\
\hline \multicolumn{8}{|l|}{ Smoking } \\
\hline No & $84.8(84.1-85.4)$ & $81.8(80.8-82.8)$ & Reference & Reference & $85.1(84.0-86.2)$ & Reference & Reference \\
\hline Yes & $15.2(14.6-15.9)$ & $18.2(17.2-19.2)$ & $1.69(1.52-1.88)$ & $1.41(1.26-1.58)$ & $14.9(13.8-16.0)$ & $0.96(0.87-1.07)$ & $1.11(0.99-1.24)$ \\
\hline \multicolumn{8}{|l|}{ Self-rated heath } \\
\hline Very good/Good & $73.4(72.6-74.2)$ & $70.6(69.5-71.7)$ & Reference & Reference & $72.3(70.9-73.6)$ & Reference & Reference \\
\hline Regular/Poor/ & $26.6(25.8-27.4)$ & $29.4(28.3-30.5)$ & $1.37(1.27-1.48)$ & $1.19(1.09-1.29)$ & $27.7(26.4-29.1)$ & $1.09(1.00-1.19)$ & $1.45(1.32-1.59)$ \\
\hline \multicolumn{8}{|l|}{ Very poor } \\
\hline \multicolumn{8}{|l|}{ Nutritional status } \\
\hline Adequate & $40.7(39.7-41.7)$ & $42.8(41.4-44.3)$ & Reference & Reference & $39.4(37.8-41.1)$ & Reference & Reference \\
\hline Underweight & $2.0(1.7-2.2)$ & $2.2(1.8-2.6)$ & $1.15(0.89-1.48)$ & $1.20(0.92-1.56)$ & $1.9(1.5-2.4)$ & $1.02(0.77-1.34)$ & $1.05(0.78-1.40)$ \\
\hline Pre-obesity & $37.0(36.1-37.9)$ & $36.7(35.4-38.0)$ & $0.88(0.80-0.96)$ & $0.85(0.77-0.93)$ & $37.3(35.8-38.8)$ & $1.06(0.98-1.16)$ & $1.09(1.00-1.19)$ \\
\hline Obesity & $19.5(18.7-20.3)$ & $17.6(16.6-18.5)$ & $0.72(0.65-0.80)$ & $0.73(0.65-0.81)$ & $20.4(19.1-21.7)$ & $1.12(1.01-1.25)$ & $1.17(1.05-1.31)$ \\
\hline
\end{tabular}

95\%Cl: 95\% confidence interval; OR: odds ratio; WMSD: work-related musculoskeletal disorder.

Note: values in bold are statistically significant $(p<0.05)$.

* Adjusted for sex, age and education.

Moreover, almost all occupational characteristics and work conditions were significantly associated with physical and psychosocial demands at work, except for night shifts and 24 hour shifts for physical demand (Table 3).

According to the final multivariate model, greater odds of physical demand were found in workers: with chronic back pain, smokers, those who self-rated their health as regular/poor or very poor, those who reported work in two or more jobs and work 20 to 40 hours a week or more than 40 hours a week. Lower odds of physical demand were observed in those classified as pre-obese or obese, and work exclusively at open environment (Table 4).

On the other hand, greater odds of psychosocial demand were found in workers who have WMSD, depression, chronic back pain, and who self-rated their health as regular/poor or very poor. And those who reported working in two or more jobs, working night shifts or 24 hour shifts, work in mixed environments (closed and open environment), have been working at the current job for 2 to 10 years or for more than 10 years, work 20 to 40 hours a week, or more than 40 hours a week (Table 5). 
Table 3

Occupational features and work conditions of Brazilian workers according to the presence of physical and psychosocial demands. 2013 Brazilian National Health Survey.

\begin{tabular}{|c|c|c|c|c|c|c|c|}
\hline \multirow[t]{2}{*}{ Characteristics } & \multirow{2}{*}{$\begin{array}{l}\text { Brazilian } \\
\text { workers } \\
\%(95 \% \mathrm{CI})\end{array}$} & \multicolumn{3}{|c|}{ Physical demand } & \multicolumn{3}{|c|}{ Psychosocial demand } \\
\hline & & $\%(95 \% \mathrm{CI})$ & $\begin{array}{l}\text { Unadjusted OR } \\
\qquad(95 \% \mathrm{CI})\end{array}$ & $\begin{array}{c}\text { Adjusted * OR } \\
(95 \% \mathrm{Cl})\end{array}$ & $\%(95 \% \mathrm{CI})$ & $\begin{array}{c}\text { Unadjusted OR } \\
\qquad(95 \% \mathrm{Cl})\end{array}$ & $\begin{array}{c}\text { Adjusted * OR } \\
(95 \% \mathrm{Cl})\end{array}$ \\
\hline \multicolumn{8}{|c|}{$\begin{array}{l}\text { Number of jobs or } \\
\text { equivalent }\end{array}$} \\
\hline 1 & $95.7(95.3-96.1)$ & $95.8(95.4-96.3)$ & Reference & Reference & $94.0(93.2-94.8)$ & Reference & Reference \\
\hline 2 or more & $4.3(3.9-4.7)$ & $4.2(3.7-4.6)$ & $0.94(0.78-1.13)$ & $1.22(1.01-1.48)$ & $6.0(5.2-6.8)$ & $1.84(1.54-2.21)$ & $1.61(1.35-1.91)$ \\
\hline \multicolumn{8}{|l|}{ Night shifts } \\
\hline No & $85.1(84.4-85.8)$ & 85.8 (84.9-86.7) & Reference & Reference & $79.1(77.7-80.5)$ & Reference & Reference \\
\hline Yes & $14.9(14.2-15.6)$ & $14.2(13.3-15.1)$ & $0.89(0.80-0.98)$ & $0.91(0.81-1.02)$ & $20.9(19.5-22.3)$ & $2.02(1.82-2.25)$ & $1.92(1.73-2.14)$ \\
\hline \multicolumn{8}{|l|}{$\begin{array}{l}\text { Open or closed } \\
\text { environment }\end{array}$} \\
\hline Closed & $28.0(27.1-28.9)$ & $36.2(34.9-37.5)$ & Reference & Reference & $22.9(21.6-24.2)$ & Reference & Reference \\
\hline Open & $51.6(50.6-52.6)$ & $40.0(38.6-41.4)$ & $0.31(0.28-0.34)$ & $0.40(0.36-0.45)$ & $52.2(50.6-53.8)$ & $1.37(1.24-1.51)$ & $1.12(1.00-1.25)$ \\
\hline Mixed (both) & $20.4(19.6-21.2)$ & $23.8(22.6-25.0)$ & $0.73(0.66-0.82)$ & $0.88(0.78-0.99)$ & $24.9(23.5-26.3)$ & $1.87(1.67-2.09)$ & $1.62(1.44-1.82)$ \\
\hline \multicolumn{8}{|l|}{$\begin{array}{l}\text { Time at the } \\
\text { current job (years) }\end{array}$} \\
\hline Up to 2 & $40.0(39.1-41.0)$ & $39.9(38.5-41.2)$ & Reference & Reference & 37.7 (36.2-39.3) & Reference & Reference \\
\hline $2-10$ & $31.3(30.5-32.0)$ & $29.6(28.6-30.7)$ & $0.90(0.83-0.98)$ & $0.96(0.88-1.05)$ & $33.0(31.6-34.4)$ & $1.19(1.09-1.30)$ & $1.23(1.12-1.36)$ \\
\hline More than 10 & $28.7(27.8-29.6)$ & $30.5(29.3-31.7)$ & $1.16(1.05-1.28)$ & $1.19(1.06-1.33)$ & $29.2(27.8-30.7)$ & $1.13(1.02-1.24)$ & $1.34(1.19-1.51)$ \\
\hline \multicolumn{8}{|l|}{24 hour shifts } \\
\hline No & $98.3(98.1-98.5)$ & $98.2(97.9-98.5)$ & Reference & Reference & 96.9 (96.4-97.3) & Reference & Reference \\
\hline Yes & $1.7(1.5-1.9)$ & $1.8(1.5-2.1)$ & $1.15(0.90-1.46)$ & $1.20(0.93-1.56)$ & $3.1(2.7-3.6)$ & $3.53(2.74-4.54)$ & $3.21(2.45-4.19)$ \\
\hline \multicolumn{8}{|l|}{$\begin{array}{l}\text { Weekly workload } \\
\text { (hours) }\end{array}$} \\
\hline Up to 20 & $11.5(10.8-12.1)$ & $10.5(9.7-11.3)$ & Reference & Reference & $7.5(6.7-8.2)$ & Reference & Reference \\
\hline $20-40$ & $44.6(43.5-45.6)$ & $42.3(40.9-43.7)$ & $1.07(0.95-1.20)$ & $1.16(1.03-1.31)$ & $43.0(41.5-44.6)$ & $1.73(1.51-1.99)$ & $1.50(1.30-1.72)$ \\
\hline Over 40 & $44.0(42.9-45.1)$ & $47.2(45.8-48.7)$ & 1.41 (1.25-1.59) & $1.33(1.18-1.52)$ & $49.5(48.0-51.1)$ & $2.22(1.94-2.54)$ & $2.04(1.77-2.34)$ \\
\hline
\end{tabular}

95\% Cl: 95\% confidence interval; OR: odds ratio.

Note: values in bold are statistically significant $(p<0.05)$.

* Adjusted for sex, age and education.

\section{Discussion}

The results suggest that there is a high level of physical and psychosocial demands at work in Brazil, which were associated with health and occupational features. Individuals with chronic back pain, poor health report, two or more jobs, and higher weekly demand presented a greater chance to report physical or psychosocial demands. The physical demand was also positively associated with smoking, whereas psychosocial demand was directly associated with WMSD, and depression. Overweight and working exclusively in an open environment reduced the chance of physical demand. On the other hand, working in a mixed environment (open and closed) was directly associated with psychosocial demand, as well as night work, 2 or more years at the current job, and 24 hours work.

This is the first study to investigate physical and psychosocial demands in the Brazilian working population. Previous studies have analyzed the relationship between several occupational expositions and health outcomes, such as Oenning et al. 27 who investigated depressive disorder. However, most studies were restricted to specific occupational categories as healthcare professionals, teachers, civil servants, and oil rig workers 7,9,28. 


\section{Table 4}

Multivariate logistic regression model assessing factors associated with physical demands. 2013 Brazilian National Health Survey.

\begin{tabular}{|c|c|c|c|}
\hline Characteristics & $\begin{array}{l}\text { Model } 1 \text { * } \\
\text { OR }(95 \% \mathrm{Cl})\end{array}$ & $\begin{array}{l}\text { Model } 2 * \\
\text { OR }(95 \% \mathrm{Cl})\end{array}$ & $\begin{array}{l}\text { Model } 3 \text { * } \\
\text { OR }(95 \% \mathrm{Cl})\end{array}$ \\
\hline \multicolumn{4}{|l|}{ Health conditions } \\
\hline \multicolumn{4}{|l|}{ Chronic back pain } \\
\hline No & Reference & & Reference \\
\hline Yes & $1.29(1.17-1.44)$ & & $1.25(1.12-1.39)$ \\
\hline \multicolumn{4}{|l|}{ Smoking } \\
\hline No & Reference & & Reference \\
\hline Yes & $1.35(1.20-1.51)$ & & $1.34(1.19-1.51)$ \\
\hline \multicolumn{4}{|l|}{ Self-rated heath } \\
\hline Very good/Good & Reference & & Reference \\
\hline Regular/Poor/Very poor & $1.15(1.05-1.25)$ & & $1.12(1.02-1.22)$ \\
\hline \multicolumn{4}{|l|}{ Nutritional status } \\
\hline Adequate & Reference & & Reference \\
\hline Underweight & $1.16(0.90-1.51)$ & & $1.22(0.93-1.61)$ \\
\hline Pre-obesity & $0.86(0.78-0.94)$ & & $0.87(0.79-0.96)$ \\
\hline Obesity & $0.73(0.65-0.81)$ & & $0.74(0.66-0.83)$ \\
\hline \multicolumn{4}{|l|}{ Occupational features } \\
\hline \multicolumn{4}{|l|}{ Number of jobs or equivalent } \\
\hline 1 & & Reference & Reference \\
\hline 2 or more & & $1.07(0.89-1.29)$ & $1.30(1.06-1.59)$ \\
\hline \multicolumn{4}{|l|}{ Open or closed environment } \\
\hline Closed & & Reference & Reference \\
\hline Open & & $0.31(0.28-0.34)$ & $0.41(0.37-0.46)$ \\
\hline Mixed (both) & & $0.73(0.65-0.82)$ & $0.88(0.79-1.00)$ \\
\hline \multicolumn{4}{|c|}{ Time at the current job (years) } \\
\hline Up to 2 & & Reference & Reference \\
\hline $2-10$ & & $0.87(0.79-0.95)$ & $0.95(0.86-1.04)$ \\
\hline Over 10 & & $1.03(0.93-1.13)$ & $1.12(1.00-1.25)$ \\
\hline \multicolumn{4}{|l|}{ Weekly workload (hours) } \\
\hline Up to 20 & & Reference & Reference \\
\hline $20-40$ & & $1.07(0.95-1.20)$ & $1.19(1.05-1.34)$ \\
\hline Over 40 & & $1.40(1.24-1.58)$ & $1.45(1.28-1.65)$ \\
\hline
\end{tabular}

95\%Cl: 95\% confidence intervals; OR: odds ratio.

Note: values in bold are statistically significant $(p<0.05)$

* Adjusted for sex, age and education.

Most Brazilian workers reported physical demand at work. A study in Denmark showed that 25\% of workers engage in activities with high or very high physical demand 29 . Another study showed that $44.7 \%$ of workers rated their physical demand at work as very demanding 30 , and sometimes the demand is related to the profession. However, the place, activities developed and time at work can also be related to the physical demand of the job. Operators and manual workers in general are more exposed to physical demand compared to workers in intellectual occupations ${ }^{7}$. Occupational hazards linked to physical demand include noise, vibration, exposure to cold, and ergonomic stress from manual, repetitive tasks that require force 31 .

More than a third of Brazilian workers reported psychosocial demand. Studies in different countries showed prevalence of approximately 50\% with health professionals 32,33. Among European 
Table 5

Multivariate logistic regression model assessing factors associated with psychosocial demands. 2013 Brazilian National Health Survey.

\begin{tabular}{|c|c|c|c|}
\hline Characteristics & $\begin{array}{l}\text { Model } 1 \text { * } \\
\text { OR }(95 \% \mathrm{Cl})\end{array}$ & $\begin{array}{l}\text { Model } 2 \text { * } \\
\text { OR }(95 \% \mathrm{Cl})\end{array}$ & $\begin{array}{l}\text { Model } 3 \text { * } \\
\text { OR }(95 \% \mathrm{Cl})\end{array}$ \\
\hline \multicolumn{4}{|l|}{ Health conditions } \\
\hline \multicolumn{4}{|l|}{ Hypertension } \\
\hline No & Reference & & Reference \\
\hline Yes & $1.10(0.97-1.25)$ & & $1.12(0.99-1.27)$ \\
\hline \multicolumn{4}{|l|}{ WMSD } \\
\hline No & Reference & & Reference \\
\hline Yes & $1.80(1.42-2.28)$ & & $1.68(1.32-2.15)$ \\
\hline \multicolumn{4}{|l|}{ Depression } \\
\hline No & Reference & & Reference \\
\hline Yes & $1.70(1.44-2.01)$ & & $1.74(1.47-2.06)$ \\
\hline \multicolumn{4}{|l|}{ Chronic back pain } \\
\hline No & Reference & & Reference \\
\hline Yes & $1.32(1.18-1.48)$ & & $1.30(1.16-1.46)$ \\
\hline \multicolumn{4}{|l|}{ Self-rated heath } \\
\hline Very good/Good & Reference & & Reference \\
\hline Regular/Poor/Very poor & $1.31(1.19-1.44)$ & & $1.36(1.23-1.49)$ \\
\hline \multicolumn{4}{|l|}{ Nutritional status } \\
\hline Adequate & Reference & & Reference \\
\hline Underweight & $1.02(0.76-1.36)$ & & $1.08(0.80-1.47)$ \\
\hline Pre-obesity & $1.08(0.99-1.17)$ & & $1.05(0.96-1.15)$ \\
\hline Obesity & $1.11(0.99-1.24)$ & & $1.05(0.93-1.18)$ \\
\hline \multicolumn{4}{|l|}{ Occupational features } \\
\hline \multicolumn{4}{|c|}{ Numbers of jobs or equivalent } \\
\hline 1 & & Reference & Reference \\
\hline 2 or more & & $1.70(1.41-2.07)$ & $1.47(1.22-1.76)$ \\
\hline \multicolumn{4}{|l|}{ Night shifts } \\
\hline No & & Reference & Reference \\
\hline Yes & & $1.72(1.53-1.94)$ & $1.69(1.50-1.91)$ \\
\hline \multicolumn{4}{|l|}{ Open or closed environment } \\
\hline Closed & & Reference & Reference \\
\hline Open & & $1.36(1.24-1.51)$ & $1.09(0.97-1.23)$ \\
\hline Mixed (both) & & $1.82(1.62-2.05)$ & $1.59(1.40-1.80)$ \\
\hline \multicolumn{4}{|c|}{ Time at the current job (years) } \\
\hline Up to 2 & & Reference & Reference \\
\hline $2-10$ & & $1.18(1.08-1.29)$ & $1.23(1.11-1.35)$ \\
\hline More than 10 & & $1.13(1.03-1.25)$ & $1.32(1.17-1.49)$ \\
\hline \multicolumn{4}{|l|}{24 hour shifts } \\
\hline No & & Reference & Reference \\
\hline Yes & & $1.94(1.45-2.59)$ & $1.80(1.33-2.43)$ \\
\hline \multicolumn{4}{|l|}{ Weekly workload (hours) } \\
\hline Up to 20 & & Reference & Reference \\
\hline $20-40$ & & $1.74(1.52-1.99)$ & $1.60(1.39-1.84)$ \\
\hline More than 40 & & $2.19(1.91-2.51)$ & $2.14(1.86-2.46)$ \\
\hline
\end{tabular}

95\% Cl: 95\% confidence interval; OR: odds ratio; WMSD: work-related musculoskeletal disorder. Note: values in bold are statistically significant $(p<0.05)$.

* Adjusted for sex, age and education. 
teachers, emotional exhaustion was reported by $25.6 \% 34$. Psychic and behavioral disorders are among the leading causes of absence from public service in Brazil 35 . Approximately $7.8 \%$ of teachers reported absence because they experienced stressful situations at school 36 .

Our study found an association between physical demand and health conditions, including the association with smoking. We hypothesized that this association reflects the perception of the worker's effort, which may be higher with smokers. The physical and psychosocial demands were also associated with chronic back pain, and these problems are often related to inappropriate posture during long working hours and absence of breaks. The consequences go beyond reducing work performance, also affecting the quality of life and limiting daily activities 37 . In South Korea, for example, the most frequently reported work-related symptoms are musculoskeletal disorders followed by stress and fatigue 38 , this result can be seen in our study, since individuals who reported poorer self-related health had higher odds of physical and psychosocial demand compared to individuals who rated their health positively.

High demand was associated to noncommunicable chronic diseases that will have long-term effects on health, quality of life, and costs for health system and employers 39 . A previous study using PNS data indicated regional and gender differences in the prevalence of musculoskeletal disorders, including WMSD, which was associated with the presence of comorbidities and environmental noise 8 .

Hypertension is one of the most studied health outcomes associated with stress, and the report of being diagnosed with it, surprisingly, was not associated with work demands. The direct activation of neuroendocrine responses to stressors or unhealthy behaviors, and smoking, physical inactivity or excessive alcohol consumption are the explanatory mechanisms for the increase in blood pressure 40,41. Factors such as shift work, working at night, and exposure to noise can contribute to the emergence of cardiometabolic diseases 12. However, we have found divergent results in the literature 42.

This study shows that individuals with self-reported depression have higher odds of psychosocial demand when compared to those without the disease. Nowadays, depression is among the most significant chronic diseases. A study with PNS data estimates a $2.8 \%$ prevalence of major depressive disorder in the Brazilian working population, being associated with workplace violence 27. Depression is a disabling disease because it affects the cognitive, emotional, and physical functioning of workers. It is known that the chance of absences is greater in workers diagnosed with depression, and is observed the reduction in productivity of individuals who continue to work when sick, a phenomenon called presenteeism 43. Chronic stress exposures also have been linked to hypertension, insulin resistance, musculoskeletal illness, anxiety, and depression. There is also a substantial body of literature suggesting that cumulative stress at work can lead to burnout syndrome 44 .

Overweight also has severe health consequences, being a significant illnesses risk factor, and associated with lifestyle and occupational factors. In this study, overweight individuals had lower odds of physical demand. This result can be related to work activities that exclude people with obesity from activities that have high physical demand 45,46 . People with obesity are sometimes seen as incapable and lazy. Such situations can also lead to health problems, including damage physical and psychological. Occupational features were associated to overweight in other studies. A study with nurses found an increased risk of overweight associated with high office workers, working full-time, and working more than 40 hours per week 46 . On the other hand, a study with public servants showed that being overweight is associated with a reduction in work breaks 47.

Regarding work characteristics, this study showed that number of jobs and weekly demand are associated to physical and psychosocial demands. According to the literature, having more than one job is frequent among nurses, teachers, and physicians, which may be related to job instability, low wages, and poor working and employment conditions 33 . Longer time (years) at the current job and 24 hour shifts were also positively associated with psychosocial demand. These variables may indicate a greater responsibility of the worker and pressure on management or coordination positions can result in stressful situations. Employment in health care, social work, and education also suggest associations with psychological distress 34 . Therefore, reducing demand and improving the working environment can play a significant role in reducing job stress.

Working night shifts or in a mixed environment (open and closed) was also directly associated with psychosocial demand. On the other hand, work in an open environment was negatively associated with physical demand, this type of work can be related to changes in circadian rhythm, sleep dis- 
turbances, stress, and unhealthy habits 12 . Furthermore, a review and meta-analysis showed that night work or shift work has a higher psychosocial demand and is associated with depressive disorders or symptoms ${ }^{48}$. Surprisingly, people who work in an open environment had a lower chance of physical demand, when compared to those who work exclusively indoors, which may be associated with the type of work, but this variable was not analyzed in our study.

These results strengthen the need to consider the demands of work when addressing health, for this, it is essential to obtain accurate information about working conditions. Despite the PNS advance in including the module $\mathrm{M}$ about worker health, it is still necessary to deepen this study, taking international surveys as example 20,21,22,23. These studies can provide significant data and inputs, besides highlighting what is happening inside the workplace 49 .

The methodological limitations to define physical and psychosocial demands require caution when interpreting the results. The definition of these outcomes varies in literature and different characteristics are used to define the physical and psychosocial demands. However, we chose to use the most significant factors, the physical effort at work and activities that lead to stress, as markers of physical and psychosocial demands 31,39,44, which are available in PNS. Therefore, data comparison is limited. Furthermore, since outcomes and exposures were based on self-reports, there may be a reporting bias that leads to inflated associations, besides the reverse causation cannot be ruled out.

Limitations that may affect our results include the healthy worker effect. Healthy workers may be able to continue working long hours, whereas sick workers are more likely to work part time or to be away from work. Although the PNS has the advantage of avoiding the under-representation of those exposed, as the case with studies investigating samples of workers formally linked to their job, there are limits to capturing cumulative effects, especially when the source of the health problem is multifactorial. It is convenient to consider the survival bias in cross-sectional studies, since people intervene in their own situations, for example, changing jobs or moving away from stressful demands. Those who fell ill may be absent more frequently from work due to incapacity 50.

In spite of data collection has been conducted in 2013, the related associations made possible a reliable characterization of the health conditions of Brazilian workers. Notably, for the first time, there are national results on exposure to physical and psychosocial demands. The ones with association between the health situation and these demands will be useful to fill the gaps in knowledge about health and work relationships, even if the labor market is reconfigured. Furthermore, sectional studies allow for investigations of the temporal trend of the outcomes of interest, especially considering the reproduction of the PNS in 2019.

Another possible limitation of the study is that it does not include information about the main job (occupational activity). Physical and psychosocial demands, observed or self-reported, are generated in the context of production, depending on its organization and work management model, which defines the task, and whether or not it makes resources available to facilitate the implementation of strategies to regulate the workload job. These characteristics cross over as occupations and activities, being, therefore, less relevant to examine the distribution of prevalence according to the main work.

Despite these limitations, our study has significant strengths. Gaps of information are expected when the sample is limited to the workforce employed under a formal contract, excluding those segments that are difficult to address in surveys that focus exclusively on specific categories of employees in the industry, agriculture, and services groups. In fact, the new configurations of the workforce give rise to almost unavoidable research limits. Using data collected at home to analyze a sample of economically active workers the PNS can fill that gap.

Moreover, the health surveys have been conducted as valid resources for the base and evaluation of public policies 51. Since the 1970s, several countries have initiated periodic surveys with questionnaires on working conditions and health in national or transnational workers' organizations in order to identify an exposure to occupational risk factors 23 . The confirmation of the quality of the self-reported information encourages researchers to maintain this type of data collection strategy, depending on the custom and operability in populations, the advantages to identify the type of exposure and to define exposed and unexposed 39 . Another advantage is the type of sample design of the PNS and the weightings used in the analyses, which guarantee representativeness of the data for Brazil, its large regions, federative units, metropolitan areas, state capitals, and other municipalities. 
As seen, this dataset allowed an analysis of the physical and psychosocial demand scenario among Brazilian workers. The multivariate models suggest that there is a high level of physical and psychosocial demand in workers associated with the type of work and health, which reinforce the findings of previous studies. However, the recent changes in labor legislation, easing agreements between employers and employees, may lead to precarious work. There may be a tendency for increased employee turnover, number of jobs per worker, and increased weekly demand 48 . Furthermore, it may have impacts on rest and benefits, which may enhance the already high demand of Brazilian workers, resulting in the increased exploitation of available working time and the physical and psychosocial exhaustion of the working population.

Note that, measures related to workers' health and current legislation emphasize actions to be taken after the illness process or the accident, and deal little with the causes of illness, that is, the process of work 49 . The results of research such as this can subsidize and improve public policies, consolidating workers' health actions ranging from surveillance to assistance. Moreover, it is necessary to incorporate work activities as significant factors in investigating the causes of diseases. Interventions and policies designed to prevent all types of negative occupational exposures are necessary and urgent, and can contribute to improve physical and psychosocial health at work.

\section{Contributors}

P. P. Freitas contributed to the conceptualization, formal analysis, drafting of manuscript and review the final version of this manuscript, and approved its publication. M. S. Lopes contributed to the formal analysis, drafting of manuscript and review the final version of this manuscript, and approved its publication. A. A. Assunção contributed to the conceptualization and critical review the final version of this manuscript, and approved its publication. A. C. S. Lopes contributed to the conceptualization, data interpretation and review the final version of this manuscript, and approved its publication.

\section{Additional informations}

ORCID: Patrícia Pinheiro de Freitas (0000-00019355-3066); Mariana Souza Lopes (0000-00033128-7959); Ada Ávila Assunção (0000-0003-21230422); Aline Cristine Souza Lopes (0000-00019782-2606).

\section{Acknowledgments}

We thank the Brazilian Ministry of Health and the Brazilian Institute for Geography and Statistics for availability of data from participants in the 2013 Brazilian National Health Survey. We also thank Renzo Ortiz for his aid in statistical analysis. To the Brazilian National Research Council and the Brazilian Graduate Studies Coordinating Board for the financial support. 


\section{References}

1. Weevers HJA, van der Beek AJ, Anema JR, van der Wal G, van Mechelen W. Work-related disease in general practice: a systematic review. Fam Pract 2005; 22:197-204.

2. Kresal F, Suklan J, Roblek V, Jerman A, Mesko M. Psychosocial risk factors for low back pain and absenteeism among Slovenian professional drivers. Cent Eur J Public Health 2017; 25: 135-40.

3. Yang H, Hitchcock E, Haldeman S, Swanson N, Lu M-L, Choi B, et al. Workplace psychosocial and organizational factors for neck pain in workers in the United States. Am J Ind Med 2016; 59:549-60.

4. Saastamoinen P, Laaksonen M, Lahelma E, Lallukka T, Pietiläinen O, Rahkonen O. Changes in working conditions and subsequent sickness absence. Scand J Work Environ Health 2014; 40:82-8.

5. Frost P, Haahr JP, Andersen JH. Impact of work, health and health beliefs on new episodes of pain-related and general absence-taking. Scand J Public Health 2009; 37:569-76.

6. Prado CEP. Estresse ocupacional: causas e consequências. Rev Bras Med Trab 2016; 14:285-9.

7. Dias FM, Santos JFC, Lovisi LAGM. O estresse ocupacional e a síndrome do esgotamento profissional (burnout) em trabalhadores da indústria do petróleo: uma revisão sistemática. Rev Bras Saúde Ocup 2016; 41:e11.

8. Assunção AA, Abreu MNS. Factor associated with self-reported work-related musculoskeletal disorders in Brazilian adults. Rev Saúde Pública 2017; 51 Suppl 1:10s.

9. Fantini AJE, Assunção AA, Machado AF. Dor musculoesquelética e vulnerabilidade ocupacional em trabalhadores do setor público municipal em BH, Brasil. Ciênc Saúde Colet 2014; 19:4727-38.

10. Batiz EC, Nunes JIDS, Licea OEA. Prevalência dos sintomas musculoesqueléticos em movimentadores de mercadorias com carga. Production 2013; 23:168-77.

11. Batista JBV, Carlotto MS, Oliveira MN, Zaccara AAL, Barros EO, Duarte MCS. Transtornos mentais em professores universitários: estudo em um serviço de perícia médica. Rev Pesqui (Univ. Fed. Estado Rio J.) 2016; 8:4538-48.

12. Andrade RCV, Fernandes RCP. Hipertensão arterial e trabalho: fatores de risco. Rev Bras Med Trab 2016; 14:252-61.

13. Feder K, Michaud D, McNamee J, Fitzpatrick E, Davies H, Leroux T. Prevalence of hazardous occupational noise exposure, hearing loss, and hearing protection usage among a representative sample of working Canadians. J Occup Environ Med 2017; 59:92-113.

14. Aronsson G, Gustafsson K. Sickness presenteeism: prevalence, attendance-pressure factors, and an outline of a model for research. J Occup Environ Med 2005; 47:958-66.
15. Meerding WJ, IJzelenberg W, Koopmanschap MA, Severens JL, Burdorf A. Health problems lead to considerable productivity loss at work among workers with high physical load jobs. J Clin Epidemiol 2005; 58:517-23.

16. Demerouti E, Le Blanc PM, Bakker AB, Schaufeli, WB, Hox J. Present but sick: a threewave study on job demands, presenteeism and burnout. Career Development International 2009; 14:50-68.

17. Hobfoll SE. The influence of culture, community, and the nested-self in the stress process: advancing conservation of resources theory. Appl Psychol 2001; 50:337-70.

18. Damacena GN, Szwarcwald CL, Malta DC, Souza Júnior PRB, Vieira MLFP, Pereira CA, et al. O processo de desenvolvimento da Pesquisa Nacional de Saúde no Brasil, 2013. Epidemiol Serv Saúde 2015; 24:197-206.

19. Instituto Brasileiro de Geografia e Estatística. Pesquisa Nacional de Saúde, 2013. Rio de Janeiro: Instituto Brasileiro de Geografia e Estatística; 2014.

20. Ministerio de Trabajo, Empleo y Seguridad Social. Cuestionarios ECETSS. https://www.ar gentina.gob.ar/srt/observatorio-srt/encuestassalud-trabajo/ECETSS-2018/cuestionarios (accessed on 06/Oct/2020).

21. European Foundation for the Improvement of Living and Working Conditions. 6th European Working Conditions Survey (2015). Questionnaire. https://www.eurofound.europa.eu/sites/ default/files/page/field_ef_documents/6th_ ewcs_2015_final_source_master_questionnai re.pdf (accessed on 06/Oct/2020).

22. Instituto Nacional de Seguridad e Higiene en el Trabajo. Encuesta Nacional de Condiciones de Trabajo. 6 ${ }^{a}$ EWCS - España. https://www. insst.es/documents/94886/96082/Encuesta+ $\mathrm{Nacional}+\mathrm{de}+\mathrm{Condiciones}+\mathrm{de}+\mathrm{Trabajo}+6 \%$ C2\%AA+EWCS/abd69b73-23ed-4c7f-bf8f6b46f1998b45 (accessed on 06/Oct/2020).

23. Benavides FG, Merino-Salazar P, Cornelio C, Assunção AA, Agudelo-Suárez AA, Amable M, et al. Cuestionario básico y criterios metodológicos para las Encuestas sobre Condiciones de Trabajo, Empleo y Salud en América Latina y el Caribe. Cad Saúde Pública 2016; 32:e00210715.

24. Instituto Brasileiro de Geografia e Estatística. Pesquisa Nacional por Amostra de Domicílios: síntese de indicadores 2013. https://biblioteca. ibge.gov.br/visualizacao/livros/liv94414.pdf (accessed on 06/Oct/2020).

25. Duarte LF. O nervosismo como categoria nosográfica no começo do século XX. Hist Ciênc Saúde-Manguinhos 2010; 17:313-26.

26. World Health Organization. Obesity: preventing and managing the global epidemic. Geneva: World Health Organization; 2000. (WHO Technical Report Series, 894). 
27. Oenning NSX, Ziegelmann PK, Goulart BNG, Niedhammer I. Occupational factors associated with major depressive disorder: a Brazilian population-based study. J Affect Disord 2018; 240:48-56.

28. Petarli GB, Zandonade E, Salaroli LB, Bissoli NS. Estresse ocupacional e fatores associados em trabalhadores bancários, Vitória - ES, Brasil. Ciênc Saúde Colet 2015; 20:3925-34.

29. Sundstrup E, Hansen ÅM, Mortensen EL, Poulsen OM, Clausen T, Rugulies R, et al. Retrospectively assessed physical work environment during working life and risk of sickness absence and labour market exit among older workers. Occup Environ Med 2018; 75:114-23.

30. Petersen J, Kirkeskov L, Hansen BB, Begtrup LM, Flachs EM, Boesen M, et al. Physical demand at work and sick leave due to low back pain: a cross-sectional study. BMJ Open 2019; 9:e026917.

31. Harmse JL, Engelbrecht JC, Bekker JL. The impact of physical and ergonomic hazards on poultry abattoir processing workers: a review. Int J Environ Res Public Health 2016; 13:197.

32. Faraji A, Karimi M, Azizi SM, Janatolmakan $\mathrm{M}$, Khatony A. Occupational stress and its related demographic factors among Iranian CCU nurses: a cross-sectional study. BMC Res Notes 2019; 12:634.

33. Marcelino Filho A, Araújo TM. Estresse ocupacional e mental dos profissionais do centro de especialidades médicas de Aracaju. Trab Educ Saúde 2015; 13 Suppl 1:177-99.

34. Bernotaite L, Malinauskiene V. Workplace bullying and mental health among teachers in relation to psychosocial job characteristics and burnout. Int J Occup Med Environ Health 2017; 30:629-40.

35. Leão ALM, Barbosa-Branco A, Rassi Neto E, Ribeiro CAN, Turchi MD. Absenteísmo-doença no serviço público municipal de Goiânia. Rev Bras Epidemiol 2015; 18:262-77.

36. Maia EG, Claro RM, Assunção AA. Múltiplas exposições ao risco de faltar ao trabalho nas escolas da Educação Básica no Brasil. Cad Saúde Pública 2019; 35 Suppl 1:e00166517.

37. Husky MM, Ferdous FF, Compagnone P, Fermanian C, Kovess-Masfety V. Chronic back pain and its association with quality of life in a large French population survey. Health Qual Life Outcomes 2018; 16:195.

38. Park J, Lee N. First Korean Working Conditions Survey: a comparison between South Korea and EU countries. Ind Health 2009; 47:50-4.

39. Assunção AA, França EB. Anos de vida perdidos por DCNT atribuídos aos riscos ocupacionais no Brasil: estudo GBD 2016. Rev Saúde Pública 2019; 53:114.
40. Kai SHY, Ruidavets J-B, Carles C, Marquie J-C, Bongard V, Leger D, et al. Impact of occupational environmental stressors on blood pressure changes and on incident cases of hypertension: a 5-year follow-up from the VISAT study. Environ Health 2018; 17:79.

41. Guimont C, Brisson C, Dagenais GR, Milot A, Vézina M, Mâsse B, et al. Effects of job strain on blood pressure: a prospective study of male and female white-collar workers. Am J Public Health 2006; 96:1436-43.

42. Alves MGM, Braga VM, Faerstein E, Lopes CS, Junger W. Modelo demanda-controle de estresse no trabalho: considerações sobre diferentes formas de operacionalizar a variável de exposição. Cad Saúde Pública 2015; 31:208-12.

43. Cocker F, Martin A, Scott J, Venn A, Sanderson K. Psychological distress, related work attendance, and productivity loss in small-to-medium enterprise owner/managers. Int J Environ Res Public Health 2013; 10:5062-82.

44. Basu S, Qayyum H, Mason S. Occupational stress in the ED: a systematic literature review. Emerg Med J 2017; 34:441-7.

45. Cabral JS. Características do trabalho e sua associação com desfechos de peso e adiposidade: estudo transversal de base populacional [Doctoral Dissertation]. Belo Horizonte: Universidade Federal de Minas Gerais; 2019.

46. Chin DL, Nam S, Lee SJ. Occupational factors associated with obesity and leisure-time physical activity among nurses: a cross sectional study. Int J Nurs Stud 2016; 57:60-9.

47. Freitas PP, Assunção AA, Bassi IB, Lopes ACS. Excesso de peso e ambiente de trabalho no setor público municipal. Rev Nutr 2016; 29:519-27.

48. Silva MA. Os reflexos da crise econômica sobre os direitos trabalhistas no Brasil. Revista Katálysis 2019; 22:252-72.

49. Cardoso AC, Morgado L. Trabalho e saúde do trabalhador no contexto atual: ensinamentos da Enquete Europeia sobre Condições de Trabalho. Saúde Soc 2019; 28:169-81.

50. Dumas O, Moual NL, Siroux V, Heederik D, Garcia-Aymerich J, Varraso R. Work related asthma. A causal analysis controlling the healthy worker effect. Occup Environ Med 2013; 70:603-10.

51. Paniz VM, Fassa AG, Maia MF, Domingues MR, Bertoldi AD. Measuring access to medicines: a review of quantitative methods used in household surveys. BMC Health Serv Res 2010; 10:146. 


\section{Resumo}

O objetivo do estudo foi descrever a prevalência de demandas físicas e psicossociais e fatores associados entre trabalhadores brasileiros. Os dados foram obtidos da Pesquisa Nacional de Saúde de 2013. A demanda física foi definida como trabalhos que exigem esforço físico intenso ou caminhadas excessivas. A demanda psicossocial foi definida como envolvimento em atividades que levam ao nervosismo. A regressão logística multivariada foi utilizada para estimar a associação entre demandas e condições de saúde, características ocupacionais e condições de trabalho. Dos 39.590 participantes, 54,4\% relataram demandas físicas e 35,5\% demandas psicossociais no trabalho. Depois de ajustar para características sociodemográficas, as condições de saúde, características ocupacionais e condições de trabalho permaneceram associadas significativamente com a carga de trabalho física ou psicossocial. Os resultados sugerem que o trabalho no Brasil apresenta níveis elevados de demandas físicas e psicossociais. Essa demanda está associada a características ocupacionais e condições de saúde. É necessário incorporar as atividades laborais enquanto fatores importantes na investigação das causas de doenças. Além disso, são urgentes as intervenções e politicas de prevenção das exposições ocupacionais negativas, podendo contribuir para melhorar a saúde física e psicossocial no local de trabalho.

Saúde do Trabalhador; Condições de Trabalho; Local de Trabalho; Estresse Ocupacional

\section{Resumen}

El objetivo de este estudio fue describir la prevalencia y factores asociados a las exigencias físicas $y$ psicosociales entre trabajadores brasileños. Los datos se obtuvieron de la Encuesta Nacional de Salud de 2013 en Brasil. La exigencia física fue definida como trabajos que requieren un esfuerzo físico intenso o caminar excesivamente. La exigencia psicosocial fue definida como la implicación en actividades que conducen al nerviosismo. Se utilizó una regresión logística multivariada para estimar la asociación entre exigencias y condiciones de salud, características ocupacionales y condiciones laborales. De los 39.590 participantes, un 54,4\% informó de exigencias físicas y un 35,5\% de psicosociales en el trabajo. Tras el ajuste por características sociodemográficas, las condiciones de salud, características y condiciones laborales continuaron significativamente asociadas a la carga de trabajo física o psicosocial. Los resultados sugieren que en Brasil el trabajo posse una alta exigencia física y psicosocial. Asimismo, esta exigencia está asociada con características laborales $y$ condiciones de salud. Es necesario incorporar las actividades laborales como factores importantes para investigar las causas de enfermedades. Asimismo, son urgentes las intervenciones y politicas con el objetivo de prevenir exposiciones laborales negativas, $y$ pueden contribuir a mejorar la salud física y psicosocial en el lugar de trabajo.

Salud Laboral; Condiciones de Trabajo;

Lugar de Trabajo; Estrés Laboral
Submitted on 20/May/2020

Final version resubmitted on 09/Nov/2020

Approved on 17/Dec/2020 